\title{
The State-of-the-Art of Urban Climate Change Modeling and Observations
}

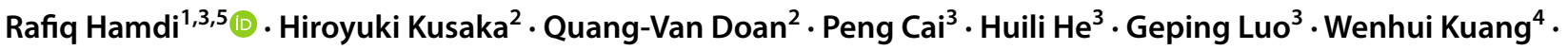 \\ Steven Caluwaerts ${ }^{1,5} \cdot$ François Duchêne $^{1} \cdot$ Bert Van Schaeybroek ${ }^{1} \cdot$ Piet Termonia $^{1,5}$
}

Received: 22 July 2020 / Accepted: 19 November 2020 / Published online: 29 November 2020

(c) The Author(s) 2020

\begin{abstract}
As an effect of climate change, cities need detailed information on urban climates at decision scale that cannot be easily delivered using current observation networks, nor global and even regional climate models. A review is presented of the recent literature and recommendations are formulated for future work. In most cities, historical observational records are too short, discontinuous, or of too poor quality to support trend analysis and climate change attribution. For climate modeling, on the other hand, specific dynamical and thermal parameterization dedicated to the exchange of water and energy between the atmosphere and the urban surfaces have to be implemented. Therefore, to fully understand how cities are impacted by climate change, it is important to have (1) simulations of the urban climate at fine spatial scales (including coastal hazards for coastal cities) integrating global climate scenarios with urban expansion and population growth scenarios and their associated uncertainty estimates, (2) urban climate observations, especially in Global South cities, and (3) spatial data of high resolution on urban structure and form, human behavior, and energy consumption.
\end{abstract}

Keywords Urban heat island · Urban climate $\cdot$ Urbanization $\cdot$ Climate change $\cdot$ Modeling $\cdot$ Monitoring network

\section{Introduction}

Nowadays, $55 \%$ of the global population lives in urban areas (Seto et al. 2017). By 2050, it is projected that the urban population will be increased by more than 2.5 billion with an associated $70 \%$ increase in urbanization rate (Grimm et al. 2008; Seto et al. 2017; Kuang 2019a). Efforts towards environmental sustainability have to be, therefore, on the front line to improve the habitability in cities as well as to maintain a sustainable biodiversity in rural areas while promoting

Rafiq Hamdi

Rafiq.hamdi@meteo.be

1 Royal Meteorological Institute of Belgium, Brussels, Belgium

2 Center for Computational Sciences, University of Tsukuba, Tsukuba, Japan

3 Binjiang College, Nanjing University of Information Science \& Technology, Wuxi, China

4 Institute of Geographic Sciences and Natural Resources Research, Chinese Academy of Sciences, Beijing, China

5 Department of Physics and Astronomy, Ghent University, Ghent, Belgium economic development. Urban areas are already vulnerable to heat wave episodes and floods, and the globally projected urban growth will increase their vulnerability (Rosenzweig et al. 2018). Urban citizens are exposed to additional heat stress due to the urban heat island with warmer near-surface air temperature in urban centers compared to the surrounding areas. As the urban dwellers are unable to recover from extreme temperature during daytime, the urban heat island (UHI) effect can be particularly detrimental to public health during heat waves (De Troeyer et al. 2020). Land-use and land-cover changes (LULCC) are expected to strongly impact climate warming trajectories in the near future (Cugnon et al. 2019; IPCC 2019; Kuang 2020b). Optimizing LULCC may lead to reduced climate warming at regional scale, as well as increased carbon sequestration. Therefore, to achieve the UN 2030 Sustainable Development Goals, it is critical to improve the quality of human settlements (Kuang 2020a).

Cities alter the local weather and climate conditions by perturbing temperature, moisture, surface energy and radiation fields, wind, and turbulence as compared to rural environments. Another unique feature of cities is the release of the anthropogenic heat flux from energy consumption 
(Ichinose et al. 1999; Bohnenstengel et al. 2014; Ma et al. 2017; Kuang 2019b). A well-known phenomenon is the socalled UHI. Three main factors contribute to the establishment of the UHI: 3-D urban geometry, thermal characteristics of impervious surfaces, and anthropogenic heat (see Fig. 1). There is also a strong contribution of local background climate to the UHI magnitude (Zhao et al. 2014; Ward et al. 2016). As can be seen from Fig. 1, 3-D urban geometry (vegetation) is the most important factor contributing to the development (mitigation) of the UHI phenomena independently from the background climate. The anthropogenic heat release comes as the second important factor for the UHI development with a bigger contribution than that of the thermal parameters of the urban materials used for the building construction. The presence of urban vegetation and water apparently leads to urban cooling to the point of negating the UHI effect completely.

Cities are also subject to other phenomena such as the urban dryness island that refers to the lower relative humidity in cities as compared to more rural locations (Jia 2020) and the urban wind island where cities experience slower wind speeds as compared to their adjacent suburban and countryside (Wu et al. 2017; Bader et al. 2018). Finally, during periods of heavy rainfall, the urban hydrological system has to cope with a large amount of surface runoff water due to the large fraction of impermeable surface (Hamdi et al. 2011).

Only one very recent review paper has been published by Masson et al. (2020) on urban climate and climate change. As a complement, in this review article, we present the state-of-the art of observations and modeling of the urban climate in Sects. 2 and 3, respectively. Sections 4 and 5 contain information about the observed urban climate trend and its interaction with global and regional-scale change, respectively. Section 6 provides a literature review of future urban climate under global climate change as a complement to Masson et al. (2020). Sections 7 and 8 provide, respectively, information for two use case studies, one for the city of Brussels (Belgium) and the other one for three Asian mega-cities representing both developed and developing countries. Section 9 provides the main conclusions and recommendation from this review article.

\section{Observations in Cities}

A typical city has a horizontal equivalent diameter ranging from a few kilometers to a few tens of kilometers and has structural features that influence the air flow at dimensions of few $10 \mathrm{~m}$ vertically (street canyon). According to Britter and Hanna (2003), length scales in the urban environment can be divided into four conceptual ranges: street scale (less than $100 \mathrm{~m}$ ), neighborhood scale (up to 1 or $2 \mathrm{~km}$ ), city scale (up to 10 or $20 \mathrm{~km}$ ), and greater metropolitan and regional scale (up to 100 or $200 \mathrm{~km}$ ). Therefore, the siting of an urban station depends on an appreciation of the concept of scale. Urban station networks can be, therefore, classified according to the aforementioned four scales (Muller et al. 2013). Since, in an urban environment, the standard conditions prescribed for meteorological and climatological observations by WMO (2017) cannot be met due to the 3-D geometry of the city environment, Oke (2006) has published a WMO report about guidelines to obtain representative meteorological observations at urban sites.

Consider, for example, the urban canopy layer which is defined roughly as the air layer below the roof level. In this layer, the thermal and dynamical perturbation are very complex and depend on the 3-D geometry of the street canyon.

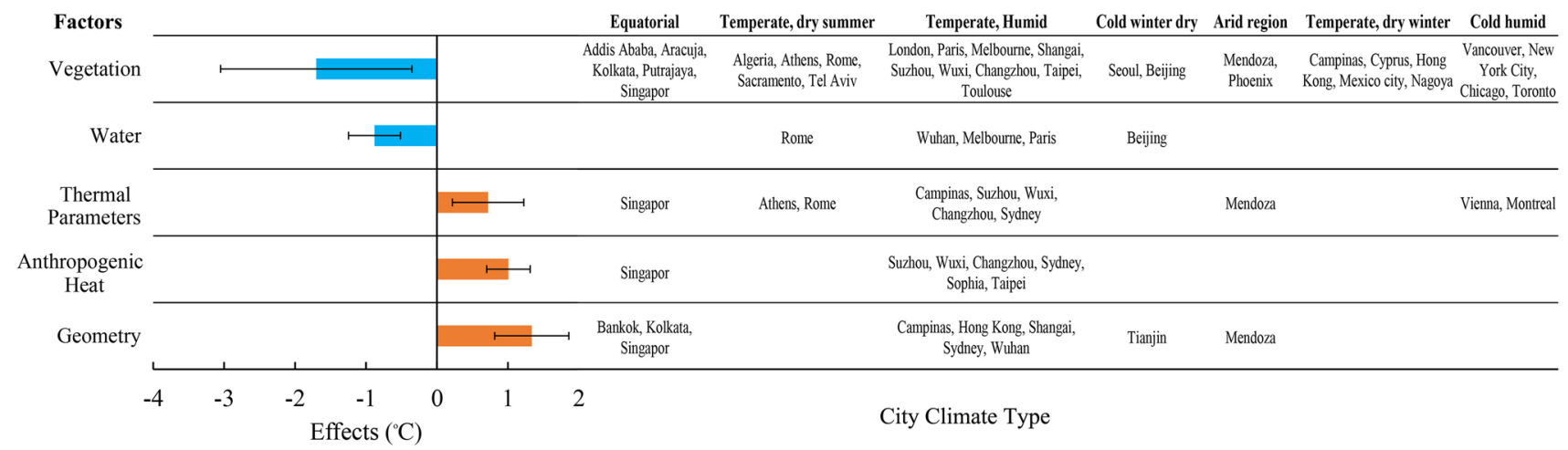

Fig. 1 Factors contributing to the development of the UHI in different cities around the world under different background climate. Data are compiled from the recent literature since 2007 (www.iauc.org newsletter bibliography section). The red and blue colors bars represent, respectively, positive and negative mean observed and/or modeled values. Horizontal black bars represent the standard deviation. Thermal parameters represent albedo, emissivity, heat capacity, and thermal conductivity of urban materials 
Measurements in this layer are therefore strongly determined by microscale features. Considering homogeneous urban areas and by horizontal averaging, the neighborhood scale restores homogeneity of the urban surfaces at a scale large enough to filter out repetitive surface inhomogeneity at the street canyon scale. Finally, the roughness sublayer extends from the surface up to a height in the vertical at which horizontal homogeneity of the flow is achieved. Barlow (2014) pointed out that a significant part of the atmospheric boundary layer can be occupied by the roughness sublayer in particular in areas with high buildings, and that roughness sublayer turbulence characteristics, inconsistent to the ones in the above inertial sublayer, can significantly affect dispersion characteristics in an urban environment. Local advection and horizontal turbulent transports are not negligible within the roughness sublayer; moreover, time averaged turbulence statistics and flux densities averaged over time are horizontally and vertically inhomogeneous (Salmond et al. 2012; Roth et al. 2015; Sugawara et al. 2016; Kuang et al. 2020).

At the city and regional scales, the altered surface conditions and modified urban surface exchange results in the well-known urban climate phenomenon known as the UHI, and these spatial scales focus on the whole boundary layer and its modification due to the presence of an urban environment. Both scales focus on the modification of the whole boundary layer. Processes in the urban roughness sublayer and the canopy sublayer are not of central importance at this spatial scale. The urban heat island generally prevails at night because of a faster cooling of rural areas compared to the urban ones. Across large mega-cities, UHI magnitude of up to $10-12{ }^{\circ} \mathrm{C}$ has been measured under certain weather conditions (Bader et al. 2018) where thermodynamically driven regional flows can be induced (Oke et al. 2017).

For numerous studies on the UHI, the scarcity of in situ measurement networks with high spatial density and qualitycontrolled observations remains a strong limiting factor even for the measurements of standard meteorological variables across urban areas. Moreover, when present, such measurements are frequently limited to measurement campaigns, and long-term datasets (more than year), as required for urban climatology, remain very scarce. They provide very useful information on the seasonal evolution of the urban climate at the decision scale for decision-makers, end-users, stakeholders, and the end-users.

Several urban networks have been set up recently. One wellknown example is the Helsinki Testbed (Wood et al. 2013). This network aims to (1) help better understanding of process at mesoscale that can be implemented in weather forecast and dispersion modeling, (2) validate and calibrate satellite products, (3) provide verification data and initial conditions for climate research models, operational forecast models, and dispersion models, (4) develop end-user products and create an integrated information system (e.g., the Helsinki Testbed data archive), and (5) disseminate mesoscale meteorological and air quality data for both the research community and the general public. Another interesting example is the Tokyo Metropolitan Area Convection Study (TOMACS; Nakatani et al. 2015) using dense meteorological networks, and TOMACS aims to better understand the mechanisms and processes related to extreme weather such as torrential rainfall, lightning, and tornadoes in the Tokyo metropolitan district. In collaboration with related government institutions, private companies, local government, and residents, TOMACS aims to develop a predicting and monitoring early warning system of extreme phenomena, and to implement social experiments on extremeweather-resilient cities. In addition, a number of major field campaigns in different cities around the world have been conducted (1) in USA, for example URBAN 2000 (Allwine et al. 2002); Joint Urban 2003 (Allwine et al. 2004); Pentagon Shield (Warner et al. 2007); Madison Square Garden (Hanna et al. 2003); (2) in Europe, for example ESCOMPTE (Mestayer et al. 2005); CAPITOUL (Masson et al. 2008); BUBBLE (Rotach et al. 2005); DAPPLE (Arnold et al. 2004), MOCCA (Caluwaerts et al. 2020), and for examples in the city of Szeged (Skarbit et al. 2017) and Novi Sad (Secerov et al. 2015; Šećerov et al. 2019). Finally, there is still a need to harmonize collection practice, instrumentation, station location, and quality controls across cities to facilitate collaborative research (Muller et al. 2015).

In the last decade, more crowdsourcing data are becoming available for the urban climate community, through the use of cheap sensors available in real time (IoT technology) that are built in various applications, e.g., in cars or in amateur weather stations in citizen science projects, etc. (e.g., see review of Muller et al. (2015). While they are far less reliable and accurate than the professional observations, they are abundantly available, despite their limited public accessibility (since they are mostly owned by private companies), and can give spatial representations with very high spatial resolutions. These sensors have larger errors than professional ones and the resulting data sets are much noisier than the ones have dealt with so far. However, this strong technological trend should be taken seriously and the urban climate community is making efforts to understand how far these data are usable, at least as a complement to the traditional meteorological data (e.g., Meier et al. (2017)). Stated differently, there is a need to develop methods to identify the signal-to-noise ratios of such crowdsourcing data in comparison to the data that are developed and used by the meteorological community. 


\section{Urban Parameterization in Climate Models}

Specific dynamical and thermal parameterizations dedicated to the exchange of energy and water between the urban surfaces and the atmosphere have to be implemented in climate models to take into account the interactions between the surface and the atmosphere of the cities (Fig. 2).

These schemes were strongly developed after the year 2000 and vary considerably in their complexity. In general, three different types can be distinguished (Kusaka et al. 2001a; Masson 2006; Grimmond et al. 2010, 2011; Chen et al. 2011; Best and Grimmond 2015):

(i) Slab or bulk approach by modifying soil and vegetation parameters in the Soil-Vegetation-Atmosphere transfer models. They generally apply an updated roughness classification following evidences from observational studies, which indicate that both roughness length and displacement height are extra-large over cities. To take into account the anthropogenic heat fluxes, radiation trapping in the urban canopy, heat storage, and evaporation, the energy balance is also modified. However, these models do not resolve the three-dimensional structure of the city. (ii) In single-layer urban canopy modules (embedded within the lowest model layer), they are best fitted for use for a typical dense city center. They represent the city with a simplified urban canyon geometry that is able to capture almost all the 3-D physical process influencing the radiative and energy fluxes (Masson 2000; Kusaka et al. 2001b).

(iii) Multi-layer urban canopy modules integrate a direct interaction with the planetary boundary layer, since the urban effects are computed vertically throughout the urban canopy (Martilli et al. 2002; Hamdi and Masson 2008).

Since 2010, global climate modeling groups have begun to implement urban parameterization within the land surface scheme of their global circulations models. McCarthy et al. (2010) investigated the changes in the UHI intensity under doubled $\mathrm{CO}_{2}$ conditions and anthropogenic heat scenarios using the Hadley Center Global Climate Model coupled to the bulk parameterization of (Best et al. 2006). Similarly, Oleson et al. (2011) used the Community Atmosphere Model version 3.5 coupled to the Community Land Model-Urban single-layer module. Recently, Chen et al. (2016b) introduced an estimate of the global distribution of anthropogenic heat release into a global climate model. Modeling groups working at the regional

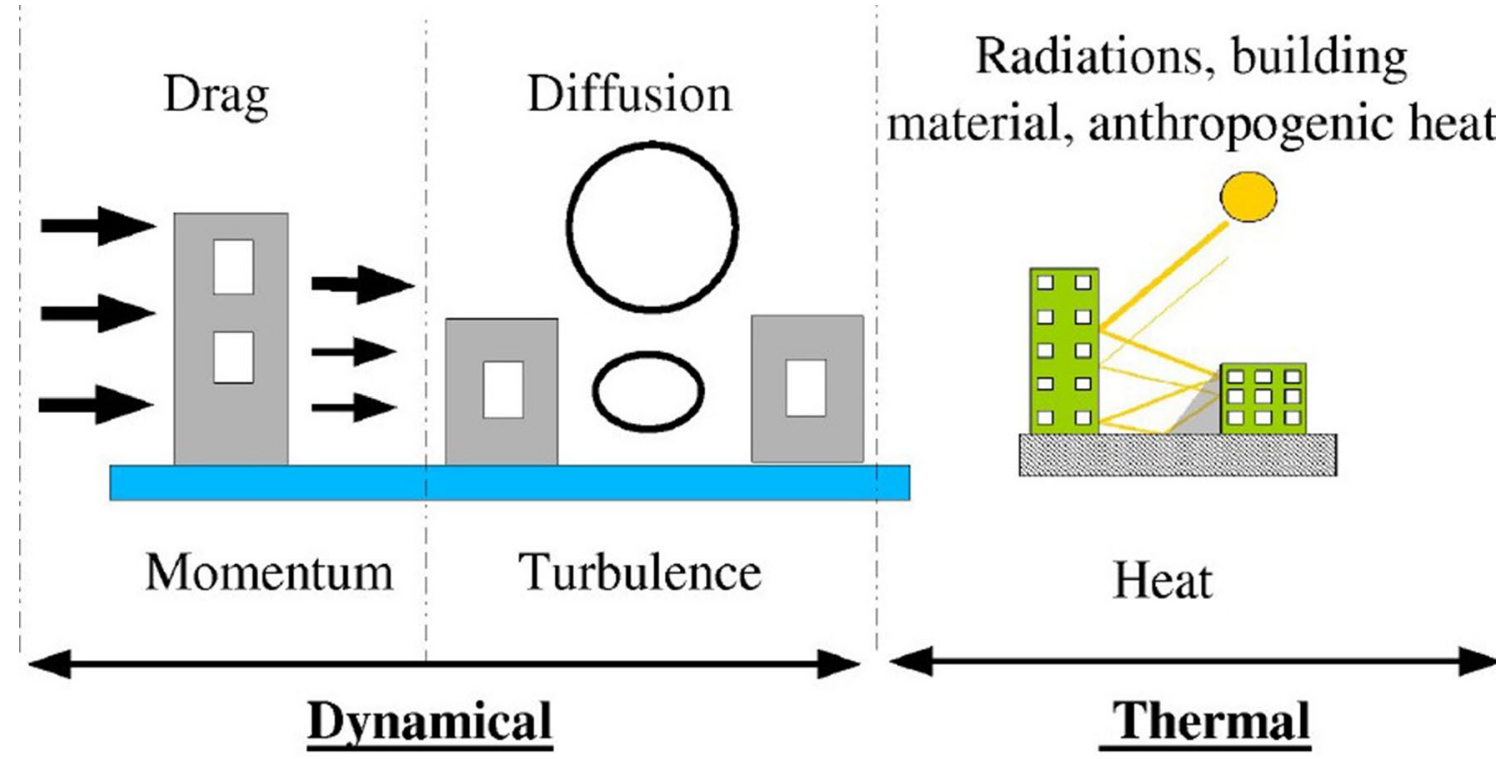

Fig. 2 Schematic representation of the dynamical and thermal effect of urban environment. The principal dynamical effects of buildings on airflow close to ground are: (1) drag forces induced by vertical surfaces of the buildings with an associated loss of momentum, (2) friction forces from horizontal surfaces (canyon floors and roofs), with an associated loss of momentum, and (3) a more intense generation of turbulent kinetic energy from mean kinetic energy. In general, the exchanges of momentum on the vertical surfaces (walls) are parameterized as the effect of pressure and drag forces induced by the buildings. The main thermal effect of the buildings is: (1) the calculation of the radiation (short and long wave) taking into account shadowing and radiative trapping effects of the buildings. View factors are computed, while multiple reflections of the incident solar radiation and long-wave reemission between walls and canyon floors are considered, (2) anthropogenic heat release, and (3) thermal parameters representing albedo, emissivity, heat capacity, and thermal conductivity of urban materials 
scale are also beginning to implement the three types of urban parameterizations described above within the land surface model component of their regional climate model (Kusaka et al. 2012a; Mccarthy et al. 2012; Hamdi et al. 2014; Trusilova et al. 2016). Other modeling groups generally employ a dynamical downscaling of global climate model information with a non-urbanized regional climate model, while further high-resolution simulations are often performed using some type of statistical and/or dynamical downscaling by running offline urban modules (Früh et al. 2011; Lemonsu et al. 2013; Conry et al. 2015; Lauwaet et al. 2015; Hamdi et al. 2016; Hoffmann et al. 2018; Darmanto et al. 2019; Duchêne et al. 2020). Finally, recent studies on the urban parameterization comparison (Kusaka et al. 2012b; Best and Grimmond 2015; Trusilova et al. 2016; Jänicke et al. 2017; Daniel et al. 2018) all suggest that a simple single-layer parameterization is sufficient for UHI modeling at regional scale and that we should take into account the requirement for increasing model complexity against what is actually needed for urban climate modeling.

\section{Urban Climate and Global Scale Change}

The impact of urban land cover on the global weather and climate is considered negligible by global climate modeling groups, since the cities cover only $0.2 \%$ of the world's land area. Lamptey (2010) showed, from an analytical approach, that urbanization produces globally $0.12 \mathrm{~W} \mathrm{~m}^{-2}$ and $0.08 \mathrm{~W} \mathrm{~m}^{-2}$ of sensible and latent heat flux, respectively, which has a minimal impact on the global climate compared to the other cover types (water, forest, vegetation, and desert). Zhang et al. (2013) and Chen et al. (2016b) introduced an estimation of the anthropogenic heat released globally as an external energy source into the lowest model layer of a global climate model. They found that while the global mean surface air temperature responses are insignificant $(0.01 \mathrm{~K}$ annual mean), they are statistically significant with a change up to $1 \mathrm{~K}$ in mid and high latitude in winter and autumn over Eurasia and North America.

The winter mid-latitude jet has been simulated with an equatorward shift with increasing westerly wind at $20^{\circ} \mathrm{N}$ and decreasing westerly wind at $40^{\circ} \mathrm{N}$. This suggests that global anthropogenic heat could produce a remote effect on surface air temperature and therefore disturb the normal atmospheric circulation.

\section{Urban Climate and Regional Scale Change}

At the regional scale, a percentage of the warming trend can be linked to the historical urbanization in rapidly industrialized countries such as China. Sun et al. (2016) found that while China's recorded annual-mean temperature increased by $1.44{ }^{\circ} \mathrm{C}$ over the period 1961-2013, urban warming influences account for about a third $\left(0.49^{\circ} \mathrm{C}\right)$. The annualmean minimum temperature is substantially more affected by urbanization than the maximum temperature (Liao et al. 2017; Wang et al. 2017). In the United States, Hausfather et al. (2013) found that urbanization accounted for between 14 and $21 \%$ of the increase of minimum temperatures since 1895 and $6-9 \%$ since 1960 (the trends vary between 0.2 and $0.6{ }^{\circ} \mathrm{C}$ per century for the period 1960-2010). Over Europe, Chrysanthou et al. (2014) show that urbanization could explain $0.003{ }^{\circ} \mathrm{C} /$ decade of the annual averaged pan-European temperature trend of $0.179{ }^{\circ} \mathrm{C} /$ decade. The strongest effect of urbanization was found in the summer $\left(0.007{ }^{\circ} \mathrm{C} /\right.$ decade $)$. A similar effect was reported in other regions Japan-(Fujibe 2009), PuertoRico-(Torres-Valcárcel et al. 2015), and other cities (Bader et al. 2018), while no effect of urbanization was observed in Saudi Arabia (Almazroui et al. 2013).

Therefore, if observations of near-surface air temperatures in growing cities are used in the assessment of global warming trends, these trends may be overestimated (Fig. 3) (Hamdi 2010; Elagib 2011; Robaa 2013; Alizadeh-Choobari et al. 2016; Sachindra et al. 2016; Lokoshchenko 2017b; Arsiso et al. 2018). This urban warming is smaller for a station that was established originally in a densely built-up area (Jones and Lister 2009). Adjusting global temperature data to remove the impacts of urban effects revealed that, for $42 \%$ of global stations, urban areas warmed at slower rates compared to the surrounding non-urban areas (Bader et al. 2018).

There is more evidence from recent observational studies that statistically significant positive anomalies in mean but also in extreme precipitation are found over and downwind of the urban areas in different climate regions of the world, especially in the afternoon and early evening, Atlanta (Haberlie et al. 2015; McLeod et al. 2017); different inland and coastal US cities (Ganeshan and Murtugudde 2015); Dutch coastal cities (Daniels et al. 2016); Hamburg (Schlünzen et al. 2010); Shanghai (Liang and Ding 2017). Over Beijing, Dou et al. (2015) found, however, that depending on the strength of the UHI, maximum precipitation values were found either over the most urbanized area of Beijing in the case of strong UHI $\left(>1.25^{\circ} \mathrm{C}\right)$ or along its downwind lateral edges for a weak UHI $\left(<1.25^{\circ} \mathrm{C}\right)$. Theoretical analysis (Han and Baik 2008) and regional climate models using urban canopy parameterizations (Trusilova et al. 2008; Kusaka et al., 2014, 2019; Pathirana et al. 2014; Ganeshan and Murtugudde 2015; Zhong and Yang 2015; Song et al. 2016; Zhong et al. 2017; Zhu et al. 2017; Li et al. 2017; Ooi et al. 2017) have been used to simulate the impact of urbanization on the precipitation patterns near urban centers. Three mechanisms could be assessed: (1) upward motion induced by the urban heat island circulation can initiate moist convection by 


\section{Change in global surface temperature: 1950-2018}

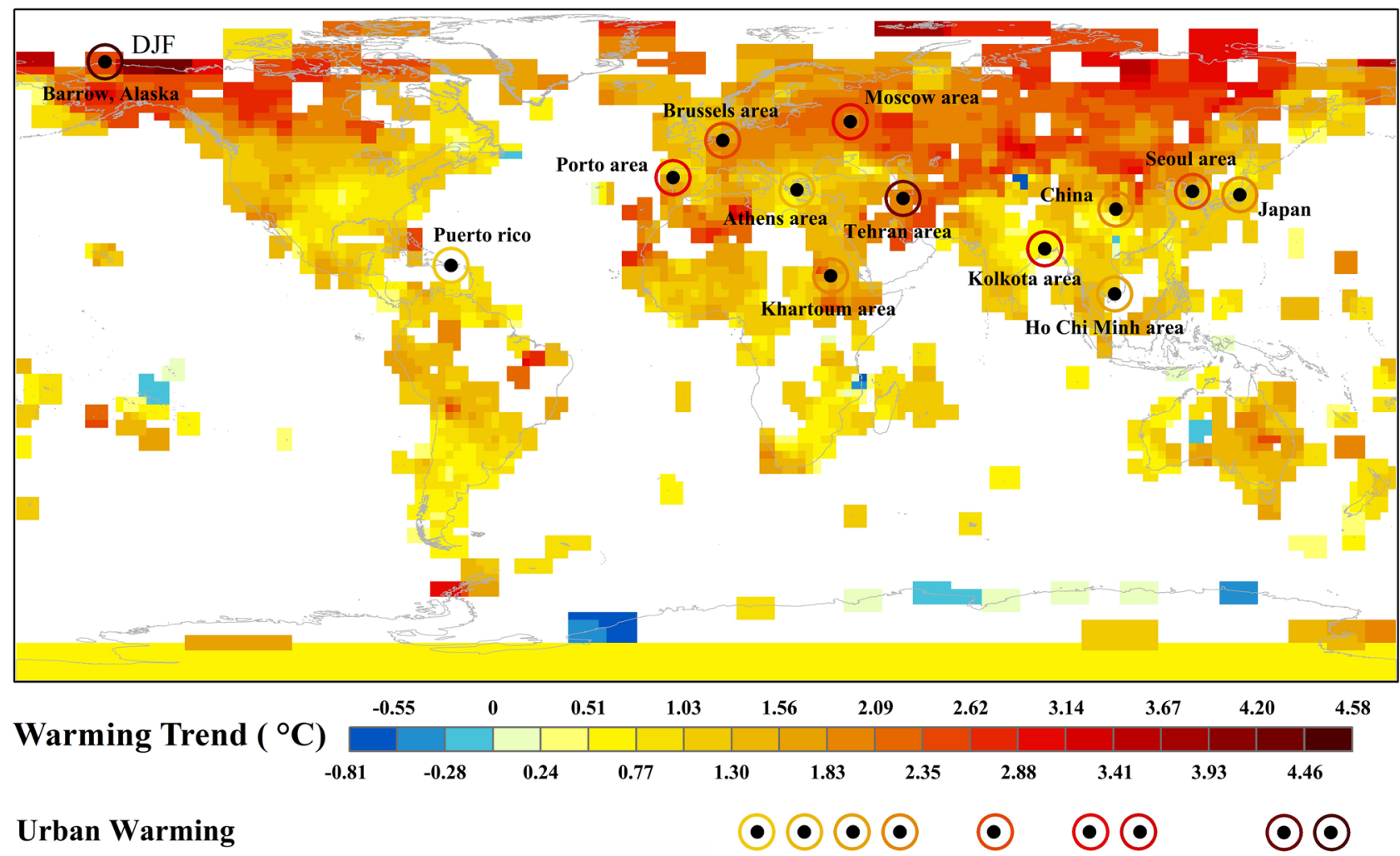

Fig. 3 Change in the annual-mean surface temperature over the period 1950-2018 based on local linear trend retrieved from the GISTEMP data (Lenssen et al. 2019). This background warming is added to the local warming that has been reported during 1950-2018 in the literature from historical urbanization in different cities and plotted on top of the background as circle for each city. Colors of the circles refer to the magnitude of the urban warming calculated as the background warming plus the historical urbanization warming. This map has been compiled using the following studies: (Ajaaj et al. 2018; Alizadeh-Choobari et al. 2016; Bader et al. 2018; Chen et al. 2016a, b; Chrysanthou et al. 2014; Doan et al. 2016; Dou et al. 2015; Elagib 2011; Founda et al. 2015; Fujibe 2009; Gaffin et al. 2008; Hinkel and Nelson 2007; Li et al. 2018a, b; Liao et al. 2017; Lokoshchenko 2017a, 2017b; Polydoros et al. 2018; Sun et al. 2016; Wang et al. 2018; Zhou et al. 2016, 2017)

as much as $10 \%$ (Zipper et al. 2017) and increasing the surface runoff (Hamdi et al. 2011).

Zhang et al. (2009) reported that upstream urbanization exacerbates UHI effects along the Washington-Baltimore corridor in the US. Similar effect was found in the Suzhou-Wuxi area (China) by Zhang and Chen (2014) and more recently over the UK by Bassett et al. (2017) where the heat advection from small urban centers increases the mean nocturnal air temperature by $0.6{ }^{\circ} \mathrm{C}$ up to a horizontal distance of $0.5 \mathrm{~km}$. There are also examples of interaction between sea-breeze front penetration and urban areas, either enhancing the sea-breeze front (Kusaka et al. 2000, 2019; Li et al. 2015) or decelerating its penetration inland (Yoshikado and Kondo 1989; Kusaka et al. 2000, 2019; Hamdi et al. 2012a; Rojas et al. 2018) and therefore impacting the spatial distribution of the urban heat island. Finally, there is also evidences of synergistic interactions between UHI and heat wave episodes making the heat wave more intense in urban than rural areas and the nocturnal UHI during heat wave 
stronger than its climatological mean: along the Washington-Baltimore corridor in the US (Li and Bou-Zeid 2013), across the Yangtze River Delta in China (Wang et al. 2017), Western Europe, Brussels (Hamdi et al. 2016), and in the Mediterranean climate, Athens (Founda and Santamouris 2017).

\section{Urban Climate Under Future Climate Change}

It is very uncertain to estimate the UHI under climate change conditions, because several studies use different methods and report contrasting results. McCarthy et al. (2010), Oleson et al. (2011), and Oleson (2012) investigated the changes in the UHI using global climate models coupled to urban canopy parameterizations. The results show that both urban and rural areas warm substantially in response to greenhouse gas induced climate change under the simulation constraints of no urban growth. In general, the rural areas warm slightly more than urban areas and therefore reduce the urban to rural contrast. The larger storage capacity of urban areas was found to buffer the increase in long-wave radiation, the sensible heat flux is reduced accordingly, and the urban air temperature warms less than rural air temperature. Some researchers (e.g., Adachi et al. 2012; Kusaka et al. 2012a, b; Mccarthy et al. 2012; Hamdi et al. 2014) used a regional climate model coupled to a single-layer urban scheme, and the results show that the relative magnitude of UHIs in the UK and Japan would remain the same, while, for Brussels, summertime rural areas were found to warm more than urban due to a soil dryness over rural areas limiting the evapotranspiration. Other studies have performed a two-step downscaling approach: first, a dynamical downscaling of the global climate model to the regional scale, and then, further high-resolution simulations are conducted with statistical downscaling (Früh et al. 2011; Hatchett et al. 2016; Sachindra et al. 2016; Arsiso et al. 2018; Hoffmann et al. 2018). These studies found an increase of the UHIs in both Hamburg and Melbourne and a decrease during the summer in Addis Ababa under climate change conditions and the urban growth constraint. Finally, in some studies the regionally downscaled model output is used to force an offline urbanized land surface scheme (Lemonsu et al. 2013; Lauwaet et al. 2015; Rafael et al. 2017). These studies report also contrasting results about the changes in the UHIs. However, the contribution and feedback processes by urban heat island and climate change are not taken into account because of the offline nature of these simulations. Finally, there is clear evidence, showing that future urbanization will increase air temperature in different areas (Mahmood et al. 2014) under both present (Doan et al. 2016; Kaplan et al. 2017; Li et al. 2018b) or future climate conditions (Georgescu et al. 2013;
Argüeso et al. 2014; Kim et al. 2016; Kusaka et al. 2016; Grossman-Clarke et al. 2017), especially on the minimum temperatures that could be comparable to the climate change signal of the near future (up to 2035) over western Europe $\left(+0.6{ }^{\circ} \mathrm{C}\right.$; Berckmans et al. 2019).

\section{Case Study on Brussels, Belgium}

In 2014, researchers from Belgium proposed a new method to quantify the averaged present and future UHI at a kilometric spatial scale over an area that covers the entire Brussels Capital Region (BCR) (Hamdi et al. 2014). A new version of the limited-area model of the ARPEGE-IFS system running at 4-km resolution called ALARO was used for the regional climate simulations (Hamdi et al. 2012b; De Troch et al. 2013; Giot et al. 2016; Termonia et al. 2018). This new version was coupled with the Town Energy Balance scheme (TEB) (Masson 2000). A stand-alone surface scheme is employed further in offline mode to downscale the regional climate projections to an urban scale of $1 \mathrm{~km}$ resolution. The method was first applied to the period 1961-1990 to test its feasibility. The evolution of UHI of Brussels for the future 2071-2100 is then studied in the context of one of the climate scenarios proposed by the IPCC, the so-called scenario A1B. The results were also compared to a simulation where the regional climate simulations did not take into account signature of the urban heat island effect and were conducted with the assumption that were conducted with the city replaced by a bare rocky surface.

\subsection{UHI of Brussels for the Present Climate}

UHI is defined here as the difference between the minimum air temperature inside the city and the minimum air temperature simulated in the surrounding rural areas. This difference was analyzed in this study for the minimum temperature (overnight) and maximum temperature (daytime), called nocturnal and daily UHI, respectively.

Nocturnal UHI is of great interest, since it has a potential impact on human health and can amplify the intensity of heat waves. Figure 4 upper left shows the spatial distribution of the nocturnal UHI averaged over 30 years. The highest values up to three degrees occur in the center of the city, while the values gradually decrease toward the periphery of Brussels. This can be explained by the higher heat storage capacity of buildings, which, in combination with a lower reflection of solar radiation, delays the nocturnal cooling compared to the rural environment. Additionally, the effects of radiation trapping within the urban canyon play an important role and were taken into account in this study. And finally, the lower percentage of vegetation in the city prevents evaporative cooling of urban areas. 

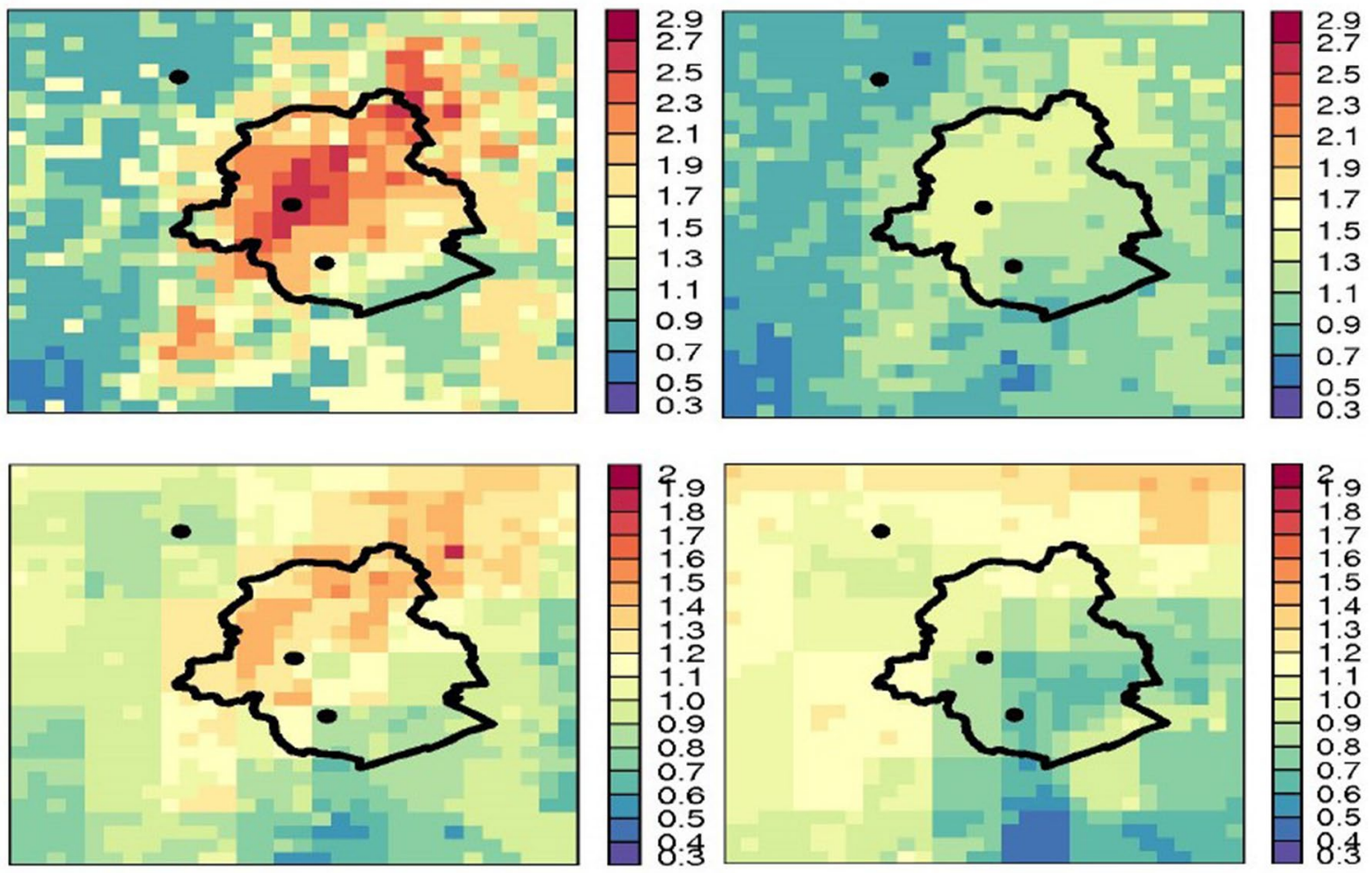

Fig. 4 The UHI of Brussels averaged over 30 years [1961-1990]. Left column using the Town Energy Balance (TEB) scheme and right column without TEB. Top nocturnal values and bottom daily values. The three black dots represent the city center of Brussels and two RMI observation stations: the Uccle station situated some $6 \mathrm{~km}$

The UHI is usually more pronounced during the night. Contrary to what has been found for the nocturnal UHI, the daily UHI (Fig. 4 lower left) is higher in the suburbs than in the city center. This is caused by the partial shading within the urban canyons in the center of the city leading to a cooling inside the street. In contrast, the daily UHI is lower in the south-eastern part of Brussels. The Sonian Forest is indeed responsible for the cooling of that area. Forests, urban parks and gardens usually reduce the heat of urban areas through shading, evaporation, and production of fresh air. Finally, the study confirms that the nocturnal UHI is higher than the daily UHI by approximately two times in the city center. With respect to the observations, the daily and nocturnal UHI values obtained when using TEB (Fig. 4 left panel) are closer to observations (Hamdi et al. 2014).

\subsection{UHI of Brussels for the Future Climate}

According to the A1B scenario, the Brussels city and the surrounding rural areas will warm considerably in response to climate change for the period 2071-2100. The warming is more pronounced for the maximum temperature than the minimum temperature (nearly three degrees for maximum south of the center of the capital in a suburban area, and the rural Brussegem station situated $13 \mathrm{~km}$ far away from the center of Brussels where the model output has been verified with respect to observations

temperature against two degrees for minimum temperature). In the future climate (see Fig. 5), under the A1B emission scenario, the two urban downscaling methods, with and without TEB, project a decrease of daytime UHI of about $-0.20{ }^{\circ} \mathrm{C}$ at the city center (Fig. 5 bottom). However, their responses are different for nocturnal UHI (Fig. 5 top): (1) the values obtained by the simulation without TEB remain unaltered (Fig. 5 top right); (2) for the simulation with TEB (Fig. 5 top left), it was found that the city warms slightly less than the suburbs and rural areas. This will therefore reduce the urban/rural contrast in the future. Indeed, the higher increase of temperatures in rural areas is related to soil dryness during the summer where the projected summer precipitation over the Brussels capital area will decrease by one-third.

Compared to the warming due to climate change (an increase of a few degrees), the magnitude of the nocturnal and daily UHI is smaller (a decrease of a few degrees in the city center). The study indicates that the nocturnal UHI will decrease in the future by three-tenths of degrees in the center of Brussels, but the UHI will always stay positive (still higher air temperatures in urban environment than in the surrounding rural areas) with values between 0 and $7^{\circ} \mathrm{C}$ 

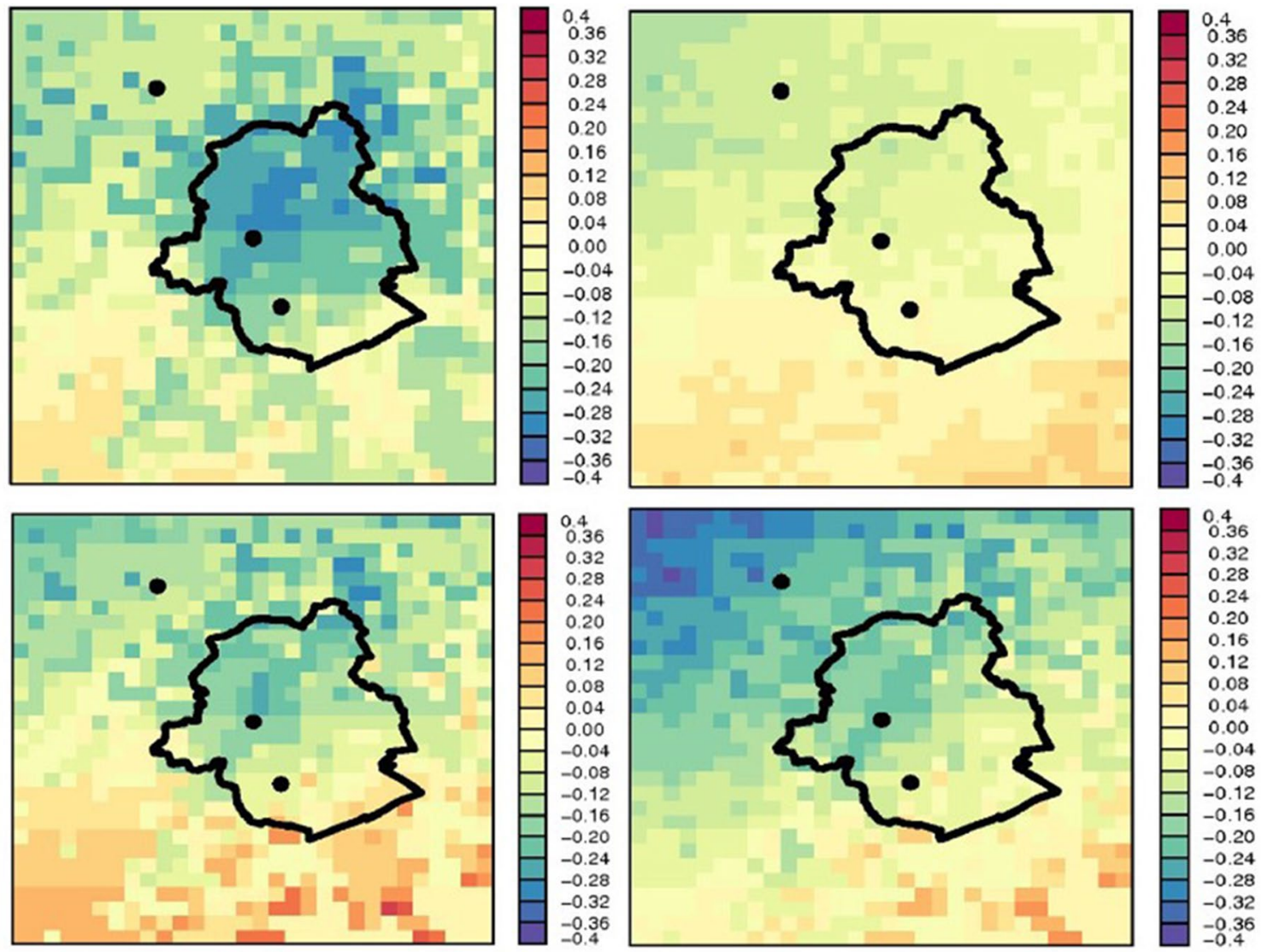

Fig. 5 2071-2100 minus 1961-1990 spatial distribution of 30-year average nocturnal (top) and daytime (bottom) UHI [ $\left.{ }^{\circ} \mathrm{C}\right]$. Left column using the town energy balance (TEB) scheme and right column without TEB

as in the current climate. The findings of this study are very important for policy makers concerned with the uncertainty of the effects of global climate change on the climate of the Brussels Capital Region. Indeed, it showed a significant positive impact of green areas on the thermal environment of urban areas, especially the role of the Sonian Forest. To be able to propagate the uncertainties from global, regional up to the city level (Duchêne et al. 2020) developed a new downscaling method combining dynamical and statistical methods with the use of a stand-alone land surface model. This method is now being applied to the EURO-Cordex ensemble and results will be published in a separate paper.

\section{Case Study on Asian Mega Cities}

In Asia, there are mature large cities such as Tokyo and cities which are developing remarkably like the ones in China and Southeast Asia. In this section, we introduce the studies of future climate projection for Tokyo and two major cities of Vietnam, Ho Chi Minh (HCM) city and Hanoi that are selected as a developing use case cities.
A reason why the mega-cities of Vietnam are selected is that those have a robust, long-term urban Master plan. Another reason is that the future urbanization of Hanoi and HCM city is greater than other mega-cities in Southeast Asia (Labbé and Boudreau 2015) and that these cities are among the most studied ones in the Southeast Asian countries with respect to climate change projections.

Study on future urban climate projection using regional climate models is roughly classified into three types:

- The first type is a high-resolution dynamical downscaling (DDS) experiment for cities while keeping the size of the city the same under future climate conditions. Here, this type is called Future Climate-Current Urban (FC-CU) experiment in this section. In this experiment, climate projections performed by the GCM are used as lateral boundary conditions. This experiment is the same as a standard DDS except that it is conducted using a regional climate model at a kilometric spatial scale and with dedicated urban parameterization embedded within its land surface model. 
- The second type of downscaling experiment is performed by running a regional climate model under current conditions using the reanalysis as a lateral boundary condition. Here, this type is called Current Climate-Current Urban (CC-CU) experiment in this section. Comparing the results of the CC-CU experiment with the results of FC-CU experiments, it is possible to study the current urban environment under future climate projections.

- The third type of downscaling experiment is done by combining future climate conditions together with future city planning scenarios. Here, this type is called Future Climate-Future Urban (FC-FU) experiment. Comparing the results of the FC-FU experiment with the results of CC-CU experiments, it is possible to more accurately evaluate the magnitude of both future global warming effect and urbanization effect.

A pioneer study of urban climate projection (FC-CU) was conducted for Tokyo Kusaka et al. (2012a, b). They present the projected urban climate for the 2070s' August under SRES A1B scenario, using the WRF model at 3-km spatial resolution and coupled to a single-layer urban canopy parameterization. The monthly average August temperatures in the 2070s are projected to be higher than those in the 2000 s by about $2.3{ }^{\circ} \mathrm{C}$ and, therefore, comparable to those in the record-breaking hot summer of 2010 . The reason why such a research is attracting attention in Japanese mega-cities is that as the summer is very hot and humid, there is a strong concern that the total number of future heat stroke patients as well as the cooling demand will increase. Indeed, the combined effect of both urbanization and global warming increases the summertime heat stress in Japan. It has come to the point that the number of heat stroke casualties has reached the number of more than 1000 per year, putting this threat greater than other natural disasters such as typhoons or tornados (Fujibe 2018).

Recently, urban climate projection considering future urban planning scenario, i.e., FC-FU experiment, has been conducted. Adachi et al. (2012) studied the projected future urban climate of Tokyo under the assumption that the expansion of Tokyo in the past 30 years will continue as it is. They found that future global warming for the 2070s under the A1B scenario will have the larger contribution from the future urban warming rather than the future urbanization. Kusaka et al. (2016) computed the future urban climate projection in 2050s under RCP4.5 scenario, assuming both a compact-city and a distributed-city scenario for greater Tokyo. The projected temperature increase in the plain was reduced by $0.2{ }^{\circ} \mathrm{C}$ in the compact-city scenario compared to the status quo scenario, while an increase of $0.3{ }^{\circ} \mathrm{C}$ was been simulated by the dispersed city scenario in the wide area surrounding central Tokyo, suggesting that the alternative urban scenarios have little impact on Tokyo's thermal environment. This result is consistent with the results of Brussels (Hamdi et al. 2015), but different from Beijing (Yan et al. 2016), Hanoi (Lee et al. 2017), HCM city (Doan and Kusaka 2018), and US cities (Georgescu et al. 2013). This might be due to the fact that Tokyo is a mature metropolis, with little remaining opportunity for significant changes in its urban structure. In Japan, when making future urban planning, it is necessary to respond to tsunami disasters due to earthquake while considering adaptation to future heat stress, as well. Urbanization influences precipitation as well as temperature, especially in the case of mega-cities. In Tokyo, summertime heavy rainfalls are of concern to citizen. Nevertheless, almost all of the numerical studies are case studies, focusing on a specific rainfall event. Kusaka et al. (2014) conducted sensitivity experiment with/without urban areas based on an ensemble, regional climatological simulations that was the first attempt. The results showed that the past and the idealized future urbanizations cause a statistically significant and robust increase in the amount of heavy precipitation in Tokyo and reduction in the surrounding inland areas.

The growth of the industrialization and urbanization of Hanoi has reach unpreceded levels, since the country opened to the market economy in the late 1980s. Its inhabitants went from about 0.9 million to over 3 million between 1990 and 2010. At this rate, it is projected to reach approximately 10 million people by 2030 as the urbanization progress. This development is the fastest in Southeast Asia countries (Labbé and Boudreau 2015). Lee et al. (2017) compared the future urbanization effect of Hanoi with the future global climate change effect for the 2030s horizon under RCP 4.5 and 8.5 scenarios (FC-FU). Here, the Master plan is used for future urban planning scenarios. The results indicated that the temperature increase due to global climate change and local urbanization is at most $70 \%$ and $30 \%$, respectively. This is completely different from Tokyo case, as shown in Adachi et al. (2012) and Kusaka et al. (2016). Doan et al. (2019) further investigated the roles of land-use/land-cover (LULC) and anthropogenic heat $(\mathrm{AH})$ on the past, present, and future UHI effect over the greater Hanoi. The results showed that the LULC-AH coupled changes during 2010-2030 will have much greater impact on UHI than those of 1990-2010. In dense urban zones, the monthly mean surface air temperature in July is predicted to increase by $0.7^{\circ} \mathrm{C}$ by 2030 , which is a doubling of the increase of $0.35^{\circ} \mathrm{C}$ during 1990-2010.

On the other hand, (Doan and Kusaka 2018) conducted future climate projection for greater HCM (GHCM) city until 2050s. Here, the Master plan is used for future urban planning scenario. The results showed that the spatially averaged April mean temperature is projected to increase by $1.2{ }^{\circ} \mathrm{C}$ and $1.7{ }^{\circ} \mathrm{C}$ by the 2050 s under the RCP4.5 and RCP8.5 scenarios, respectively. In urban area only, the temperature increase goes to 1.7 and $2.2{ }^{\circ} \mathrm{C}$, respectively, which 
represent a further increase of $0.5{ }^{\circ} \mathrm{C}$, or an equivalent of $20-30 \%$ of the global warming. This additional heating can go over $0.8{ }^{\circ} \mathrm{C}$ during the night. The impact of future urbanization is therefore comparable to the change of the temperature induced by the climate change and should then be taken into account in future studies. (Doan and Kusaka, 2016) examined the impact of urbanization since the late 1980s on the urban heat island effect over Greater HCM city. As expected, the spatial evolution of the UHI follows the one of the urban expansion. During the last 20 years, the temperature went from 0.3 to $0.6{ }^{\circ} \mathrm{C}$ in the pre-existing urbanized and the newly urbanized area, respectively. This is mainly due to the conversion of agriculture (or grassland) to urban structure, resulting in an increase of sensible heating and a decrease in latent heating. Moreover, in the last 20 years, in the central GHCM, the increase of observed temperature was estimated at $0.64{ }^{\circ} \mathrm{C}$, while the one coming from urbanization was nearly half of it $\left(0.31^{\circ} \mathrm{C}\right)$. Therefore, urbanization may contribute by about half to the increase of surface air temperature in the central GHCM in the past 20 years. The increase in the local UHI effect due to urbanization is known to affect heat-related mortality rate even in a tropical city like GHCM, where people are likely accustomed to hot environment (Tran et al. 2018). Also, comparing the past and future urbanization effects, it is mentioning worthy that Asian mega-city like HCM city is still developing and urbanization impact should be included in the RCM when future climate projection is performed.

Finally, Kusaka et al. (2016) were the first to quantify the combined uncertainties of climate projections due to RCM and urban planning scenarios. They first showed that the impacts of urbanization plan and RCM differences are larger during the night than during the day, by at most 0.6 ${ }^{\circ} \mathrm{C}$. They also indicate that the combined uncertainties of both scenarios are significantly smaller than those of GCM projections. However, it is worth mentioning that there are large differences between the RCM with and without urban land use, indicating that this impact is comparable to the differences between GCMs.

\section{Conclusion}

Today, policy makers, urban planners, and scientists are starting to work together to further understand and monitor the interactions and feedback between climate change and urban environment to find the most adequate adaptation or mitigation options. However, detailed information on future urban climate at the decision scale is needed to maintain or even improve the quality of life in cities. Most of the global circulation models that are used for climate change research do not account for urban surfaces within their land surface schemes, because they consider that the impervious surfaces only cover between 1 and $2 \%$ of the world's land areas. The latest report from the Intergovernmental Panel on Climate Change (IPCC 2014) recognizes that urban warming has not explicitly been taken into account in climate change simulations. A special report on climate change and cities is planned for the next assessment cycle 7 .

Recently, since 2010, Global and regional climate modeling groups are beginning to implement urban parameterizations within the land surface model component of their climate models. However climate change signal projected by global or regional climate models may not capture certain mesoscale features of the urban heat island such as the thermodynamically driven regional-scale flows induced by the urban heat island circulation. Therefore, it will be necessary to set the detailed land-use map with urban areas and urban canopy parameterization when projecting future urban climate for cities. Impact assessments and adaptation plans for cities will require high spatial resolution climate projections along with:

- Urban climate observations;

- Models that represent urban processes;;

- Ensemble dynamical and statistical downscaling;

- Local-impact models.

Acknowledgements This work is supported by URCLIM, which has received funding from EU's H2020 Research and Innovation Program under Grant Agreement 690462.

\section{Compliance with Ethical Standards}

Conflict of interest On behalf of all authors, the corresponding author states that there is no conflict of interest.

Open Access This article is licensed under a Creative Commons Attribution 4.0 International License, which permits use, sharing, adaptation, distribution and reproduction in any medium or format, as long as you give appropriate credit to the original author(s) and the source, provide a link to the Creative Commons licence, and indicate if changes were made. The images or other third party material in this article are included in the article's Creative Commons licence, unless indicated otherwise in a credit line to the material. If material is not included in the article's Creative Commons licence and your intended use is not permitted by statutory regulation or exceeds the permitted use, you will need to obtain permission directly from the copyright holder. To view a copy of this licence, visit http://creativecommons.org/licenses/by/4.0/.

\section{References}

Adachi SA, Kimura F, Kusaka H, Inoue T, Ueda H (2012) Comparison of the impact of global climate changes and urbanization on summertime future climate in the Tokyo metropolitan area. J Appl Meteorol Climatol 51:1441-1454. https://doi.org/10.1175/ JAMC-D-11-0137.1 
Ajaaj AA, Mishra AK, Khan AA (2018) Urban and peri-urban precipitation and air temperature trends in mega cities of the world using multiple trend analysis methods. Theor Appl Climatol 132:403-418. https://doi.org/10.1007/s00704-017-2096-7

Alizadeh-Choobari O, Ghafarian P, Adibi P (2016) Inter-annual variations and trends of the urban warming in Tehran. Atmos Res 170:176-185. https://doi.org/10.1016/j.atmosres.2015.12.001

Allwine KJ, Shinn JH, Streit GE, Clawson KL, Brown M (2002) Overview of urban 2000. Bull Am Meteorol Soc 83:521-536. https ://doi.org/10.1175/1520-0477(2002)083\%3c0521:OOUAM F\%3e2.3.CO;2

Allwine KJ, Leach MJ, Stockham LW, Shinn JS, Hosker RP, Bowers JF et al (2004) Overview of Joint Urban 2003 an atmospheric dispersion study in Oklahoma City. PNNL-SA-40036; For presentation at the Symposium on Planning, Nowcasting, and Forecasting in the Urban Zone, Seattle, Washington

Almazroui M, Islam MN, Jones PD (2013) Urbanization effects on the air temperature rise in Saudi Arabia. Clim Change 120:109-122. https://doi.org/10.1007/s10584-013-0796-2

Argüeso D, Evans JP, Fita L, Bormann KJ (2014) Temperature response to future urbanization and climate change. Clim Dyn 42:2183-2199. https://doi.org/10.1007/s00382-013-1789-6

Arnold SJ, ApSimon H, Barlow J, Belcher S, Bell M, Boddy JW et al (2004) Introduction to the DAPPLE air pollution project. Sci Total Environ 332:139-153. https://doi.org/10.1016/j.scito tenv.2004.04.020

Arsiso BK, Tsidu GM, Stoffberg GH, Tadesse T (2018) Influence of urbanization-driven land use/cover change on climate: the case of Addis Ababa, Ethiopia. Phys Chem Earth. https://doi. org/10.1016/j.pce.2018.02.009

Bader DA, Blake R, Grimm A, Hamdi R, Kim Y, Horton R et al (2018) Urban climate science. In: Rosenzweig C, Romero-Lankao P, Mehrotra S, Dhakal S, Ibrahim SA, Solecki WD (eds) Climate change and cities. Cambridge University Press, Cambridge, pp 27-60. https://doi.org/10.1017/9781316563878.009

Barlow JF (2014) Progress in observing and modelling the urban boundary layer. Urban Clim 10:216-240. https://doi. org/10.1016/j.uclim.2014.03.011

Bassett R, Cai X, Chapman L, Heaviside C, Thornes JE (2017) The effects of heat advection on UK weather and climate observations in the vicinity of small urbanized areas. Bound Layer Meteorol 165:181-196. https://doi.org/10.1007/s10546-017-0263-0

Berckmans J, Hamdi R, Dendoncker N (2019) Bridging the gap between policy-driven land use changes and regional climate projections. J Geophys Res Atmospheres 124:5934-5950. https ://doi.org/10.1029/2018JD029207

Best MJ, Grimmond CSB (2015) Key conclusions of the first international urban land surface model comparison project. Bull Am Meteorol Soc 96:805-819. https://doi.org/10.1175/BAMSD-14-00122.1

Best MJ, Grimmond CSB, Villani MG (2006) Evaluation of the urban tile in MOSES using surface energy balance observations. Bound Layer Meteorol. https://doi.org/10.1007/s10546-005-9025-5

Bohnenstengel SI, Hamilton I, Davies M, Belcher SE (2014) Impact of anthropogenic heat emissions on London's temperatures. Q J R Meteorol Soc 140:687-698. https://doi.org/10.1002/qj.2144

Britter RE, Hanna SR (2003) Flow and dispersion in urban areas. Annu Rev Fluid Mech 35:469-496. https://doi.org/10.1146/annur ev.fluid.35.101101.161147

Caluwaerts S, Hamdi R, Top S, Lauwaet D, Berckmans J, Degrauwe D et al (2020) The urban climate of Ghent, Belgium: a case study combining a high-accuracy monitoring network with numerical simulations. Urban Clim 31:100565. https://doi.org/10.1016/j. uclim.2019.100565
Chen F, Kusaka H, Bornstein R, Ching J, Grimmond CSB, Grossman-Clarke $S$ et al (2011) The integrated WRF/urban modelling system: development, evaluation, and applications to urban environmental problems. Int J Climatol 31:273-288. https://doi. org/10.1002/joc. 2158

Chen B, Dong L, Liu X, Shi GY, Chen L, Nakajima T et al (2016) Exploring the possible effect of anthropogenic heat release due to global energy consumption upon global climate: a climate model study. Int J Climatol 36:4790-4796. https://doi.org/10.1002/ joc. 4669

Chen H, Zhang Y, Yu M, Hua W, Sun S, Li X et al (2016) Large-scale urbanization effects on eastern Asian summer monsoon circulation and climate. Clim Dyn 47:117-136. https://doi.org/10.1007/ s00382-015-2827-3

Chrysanthou A, Van Der Schrier G, Van Den Besselaar EJM, Klein Tank AMG, Brandsma T (2014) The effects of urbanization on the rise of the European temperature since 1960. Geophys Res Lett 41:7716-7722. https://doi.org/10.1002/2014GL061154

Conry P, Sharma A, Potosnak MJ, Leo LS, Bensman E, Hellmann JJ et al (2015) Chicago's heat island and climate change: bridging the scales via dynamical downscaling. J Appl Meteorol Climatol 54:1430-1448. https://doi.org/10.1175/JAMC-D-14-0241.1

Cugnon G, Caluwaerts S, Duchêne F, Hamdi R, Termonia P, Top S et al (2019) Climate sensitivity to land use changes over the city of Brussels. Geographica Pannonica 23(4):269-276

Daniels EE, Lenderink G, Hutjes RWA, Holtslag AAM (2016) Observed urban effects on precipitation along the Dutch West coast. Int J Climatol 36:2111-2119. https://doi.org/10.1002/ joc. 4458

Daniel M, Lemonsu A, Déqué M, Somot S, Alias A, Masson V (2018) Benefits of explicit urban parameterization in regional climate modeling to study climate and city interactions. Clim Dyn. https ://doi.org/10.1007/s00382-018-4289-x

Darmanto NS, Varquez ACG, Kawano N, Kanda M (2019) Future urban climate projection in a tropical megacity based on global climate change and local urbanization scenarios. Urban Clim 29:100482. https://doi.org/10.1016/j.uclim.2019.100482

De Troch R, Hamdi R, Van de Vyver H, Geleyn J-F, Termonia P (2013) Multiscale performance of the ALARO-0 model for simulating extreme summer precipitation climatology in Belgium. J Clim. https://doi.org/10.1175/JCLI-D-12-00844.1

De Troeyer K, Bauwelinck M, Aerts R, Profer D, Berckmans J, Delcloo A et al (2020) Heat related mortality in the two largest Belgian urban areas: a time series analysis. Environ Res 188:109848. https://doi.org/10.1016/j.envres.2020.109848

Doan Q-V, Kusaka H (2016) Numerical study on regional climate change due to the rapid urbanization of greater Ho Chi Minh City's metropolitan area over the past 20 years. Int J Climatol 36:3633-3650. https://doi.org/10.1002/joc.4582

Doan VQ, Kusaka H (2018) Projections of urban climate in the 2050s in a fast-growing city in Southeast Asia: the greater Ho Chi Minh city metropolitan area, Vietnam. Int J Climatol 38:4155-4171. https://doi.org/10.1002/joc.5559

Doan QV, Kusaka H, Ho QB (2016) Impact of future urbanization on temperature and thermal comfort index in a developing tropical city: Ho Chi Minh City. Urban Clim 17:20-31. https://doi. org/10.1016/j.uclim.2016.04.003

Doan VQ, Kusaka H, Nguyen TM (2019) Roles of past, present, and future land use and anthropogenic heat release changes on urban heat island effects in Hanoi, Vietnam: numerical experiments with a regional climate model. Sustain Cities Soc 47:101479. https://doi.org/10.1016/j.scs.2019.101479

Dou J, Wang Y, Bornstein R, Miao S (2015) Observed spatial characteristics of Beijing urban climate impacts on summer 
thunderstorms. J Appl Meteorol Climatol 54:94-105. https:// doi.org/10.1175/JAMC-D-13-0355.1

Duchêne F, Van Schaeybroeck B, Caluwaerts S, De Troch R, Hamdi R, Termonia P (2020) A statistical-dynamical methodology to downscale regional climate projections to urban scale. J Appl Meteorol Climatol 59:1109-1123. https://doi.org/10.1175/ JAMC-D-19-0104.1

Elagib NA (2011) Evolution of urban heat island in Khartoum. Int J Climatol 31:1377-1388. https://doi.org/10.1002/joc.2159

Flores Rojas JL, Pereira Filho AJ, Karam HA, Vemado F, Masson V (2018) Effects of explicit urban-canopy representation on local circulations above a tropical mega-city. Bound Layer Meteorol 166:83-111. https://doi.org/10.1007/s10546-017-0292-8

Founda D, Santamouris M (2017) Synergies between Urban Heat Island and Heat Waves in Athens (Greece), during an extremely hot summer (2012). Sci Rep 7:1-11. https://doi.org/10.1038/ s41598-017-11407-6

Founda D, Pierros F, Petrakis M, Zerefos C (2015) Interdecadal variations and trends of the Urban Heat Island in Athens (Greece) and its response to heat waves. Atmos Res 161-162:1-13. https ://doi.org/10.1016/j.atmosres.2015.03.016

Früh B, Becker P, Deutschländer T, Hessel J-D, Kossmann M, Mieskes I et al (2011) Estimation of climate-change impacts on the urban heat load using an urban climate model and regional climate projections. J Appl Meteorol Climatol 50:167-184. https://doi. org/10.1175/2010JAMC2377.1

Fujibe F (2009) Detection of urban warming in recent temperature trends in Japan. Int J Climatol 29:1811-1822. https://doi. org/10.1002/joc. 1822

Fujibe F, Matsumoto J, Suzuki H (2018) Spatial and temporal features of heat stroke mortality in Japan and their relation to temperature variations, 1999-2014. Geogr. Rev. Jpn. 91:17-27

Fumiaki F, Jun M, Hideto S (2018) Spatial and temporal features of heat stroke mortality in Japan and their relation to temperature variations, 1999-2014. Geogr Rev Jpn Ser B 91:17-27. https:// doi.org/10.4157/geogrevjapanb.91.17

Gaffin SR, Rosenzweig C, Khanbilvardi R, Parshall L, Mahani S, Glickman H et al (2008) Variations in New York city's urban heat island strength over time and space. Theor Appl Climatol 94:1-11. https://doi.org/10.1007/s00704-007-0368-3

Ganeshan M, Murtugudde R (2015) Nocturnal propagating thunderstorms may favor urban "hot-spots": a model-based study over Minneapolis. Urban Clim 14:606-621. https://doi.org/10.1016/j. uclim.2015.10.005

Georgescu M, Moustaoui M, Mahalov A, Dudhia J (2013) Summertime climate impacts of projected megapolitan expansion in Arizona. Nat Clim Change 3:37-41. https://doi.org/10.1038/nclim ate 1656

Giot O, Termonia P, Degrauwe D, De Troch R, Caluwaerts S, Smet $G$ et al (2016) Validation of the ALARO-0 model within the EURO-CORDEX framework. Geosci Model Dev. https://doi. org/10.5194/gmd-9-1143-2016

Grimmond CSB, Blackett M, Best MJ, Barlow J, Baik J-J, Belcher SE et al (2010) The international urban energy balance models comparison project: first results from phase 1. J Appl Meteorol Climatol 49:1268-1292. https://doi.org/10.1175/2010JAMC2354.1

Grimmond CSB, Blackett M, Best MJ, Baik J-J, Belcher SE, Beringer $J$ et al (2011) Initial results from phase 2 of the international urban energy balance model comparison. Int J Climatol. https:// doi.org/10.1002/joc. 2227

Grimm NB, Faeth SH, Golubiewski NE, Redman CL, Wu J, Bai X et al (2008) Global change and the ecology of cities. Science 319:756-760. https://doi.org/10.1126/science.1150195

Grossman-Clarke S, Schubert S, Fenner D (2017) Urban effects on summertime air temperature in Germany under climate change. Int J Climatol 37:905-917. https://doi.org/10.1002/joc.4748
Haberlie AM, Ashley WS, Pingel TJ (2015) The effect of urbanisation on the climatology of thunderstorm initiation. Q J R Meteorol Soc 141:663-675. https://doi.org/10.1002/qj.2499

Hamdi R (2010) Estimating urban heat island effects on the temperature series of Uccle (Brussels, Belgium) using remote sensing data and a land surface scheme. Remote Sens. https://doi. org/10.3390/rs2122773

Hamdi R, Masson V (2008) Inclusion of a drag approach in the town energy balance (TEB) scheme: offline 1D evaluation in a street Canyon. J Appl Meteorol Climatol 47:2627-2644. https://doi. org/10.1175/2008JAMC1865.1

Hamdi R, Termonia P, Baguis P (2011) Effects of urbanization and climate change on surface runoff of the Brussels Capital Region: a case study using an urban soil-vegetation-atmosphere-transfer model. Int J Climatol. https://doi.org/10.1002/joc.2207

Hamdi R, Degrauwe D, Termonia P (2012) Coupling the town energy balance (TEB) scheme to an operational limited-area NWP model: evaluation for a highly urbanized area in Belgium. Weather Forecast 27:323-344. https://doi.org/10.1175/WAFD-11-00064.1

Hamdi R, Van de Vyver H, Termonia P (2012) New cloud and microphysics parameterisation for use in high-resolution dynamical downscaling: application for summer extreme temperature over Belgium. Int J Climatol. https://doi.org/10.1002/joc.2409

Hamdi R, Van de Vyver H, De Troch R, Termonia P (2014) Assessment of three dynamical urban climate downscaling methods: Brussels's future urban heat island under an A1B emission scenario. Int J Climatol. https://doi.org/10.1002/joc.3734

Hamdi R, Giot O, De Troch R, Deckmyn A, Termonia P (2015) Future climate of Brussels and Paris for the 2050s under the A1B scenario. Urban Clim. https://doi.org/10.1016/j.uclim.2015.03.003

Hamdi R, Duchêne F, Berckmans J, Delcloo A, Vanpoucke C, Termonia P (2016) Evolution of urban heat wave intensity for the Brussels Capital Region in the ARPEGE-Climat A1B scenario. Urban Clim. https://doi.org/10.1016/j.uclim.2016.08.001

Han J-Y, Baik J-J (2008) A theoretical and numerical study of urban heat island-induced circulation and convection. J Atmos Sci 65:1859-1877. https://doi.org/10.1175/2007JAS2326.1

Hanna S, White J, Zhou Y, Kosheleva A (2003) ANALYSIS OF JOINT URBAN 2003 (JU2003) AND MADISON SQUARE GARDEN 2005 (MSG05) METEOROLOGICAL AND TRACER DATA. Sixth Symposium on the Urban Environment AMS Forum: Managing our Physical and Natural Resources: Successes and Challenges. 2006

Hatchett BJ, Koračin D, Mejía JF, Boyle DP (2016) Assimilating urban heat island effects into climate projections. J Arid Environ 128:59-64. https://doi.org/10.1016/j.jaridenv.2016.01.007

Hausfather Z, Menne MJ, Williams CN, Masters T, Broberg R, Jones D (2013) Quantifying the effect of urbanization on U.S. historical climatology network temperature records. J Geophys Res Atmos 118:481-494. https://doi.org/10.1029/2012JD018509

Hinkel KM, Nelson FE (2007) Anthropogenic heat island at Barrow, Alaska, during winter: 2001-2005. J Geophys Res Atmos. https ://doi.org/10.1029/2006JD007837

Hoffmann P, Schoetter R, Schlünzen KH (2018) Statistical-dynamical downscaling of the urban heat island in Hamburg, Germany. Meteorol Zeitschrift 27:89-109. https://doi.org/10.1127/ metz/2016/0773

Ichinose T, Shimodozono K, Hanaki K (1999) Impact of anthropogenic heat on urban climate in Tokyo. Atmos Environ 33:3897-3909. https://doi.org/10.1016/S1352-2310(99)00132-6

IPCC (2014). Climate change 2014: synthesis report. Contribution of working groups I, II and III to the Fifth Assessment Report of the Intergovernmental Panel on Climate Change [Core Writing Team, R.K. Pachauri and L.A. Meyer (eds.)]. IPCC, Geneva, Switzerland, pp. 151 
IPCC (2019) Climate change and land: an IPCC special report on climate change, desertification, land degradation, sustainable land management, food security, and greenhouse gas fluxes in terrestrial ecosystems. In: Shukla PR, Skea J, Buendia EC, MassonDelmotte V, Pörtner H-O, Roberts DC (eds) (In Press)

Jänicke B, Meier F, Fenner D, Fehrenbach U, Holtmann A, Scherer D (2017) Urban-rural differences in near-surface air temperature as resolved by the Central Europe Refined analysis (CER): sensitivity to planetary boundary layer schemes and urban canopy models. Int J Climatol 37:2063-2079. https://doi.org/10.1002/ joc. 4835

Jiang Z, Huo F, Ma H, Song J, Dai A (2017) Impact of Chinese urbanization and aerosol emissions on the East Asian summer monsoon. J Clim 30:1019-1039. https://doi.org/10.1175/ JCLI-D-15-0593.1

Jia TB, Ren G, Zhao X, Zhang P, Li X (2020) Half-century urban drying in Shijiazhuang City. Environ Res Commun 2:075006

Jones PD, Lister DH (2009) The urban heat island in central London and urban-related warming trends in central London since 1900. Weather 64:323-327. https://doi.org/10.1002/wea.432

Kaplan S, Georgescu M, Alfasi N, Kloog I (2017) Impact of future urbanization on a hot summer: a case study of Israel. Theor Appl Climatol 128:325-341. https://doi.org/10.1007/s0070 4-015-1708-3

Kim H, Kim YK, Song SK, Lee HW (2016) Impact of future urban growth on regional climate changes in the Seoul Metropolitan Area. Korea Sci Total Environ 571:355-363. https://doi. org/10.1016/j.scitotenv.2016.05.046

Kuang W (2019b) New evidences on anomalous phenomenon of buildings in regulating urban climate from observations in Beijing, China. Earth Space Sci 6:861-872. https://doi. org/10.1029/2018EA000542

Kuang W (2019a) Mapping global impervious surface area and green space within urban environments. Sci China Earth Sci 62:15911606. https://doi.org/10.1007/s11430-018-9342-3

Kuang W (2020a) 70 years of urban expansion across China: trajectory, pattern, and national policies. Sci Bull 65(23):1970-1974. https ://doi.org/10.1016/j.scib.2020.07.005

Kuang W (2020b) National urban land-use/cover change since the beginning of the 21 st century and its policy implications in China. Land Use Policy 97:104747. https://doi.org/10.1016/j. landusepol.2020.104747

Kuang W, Li Z, Hamdi R (2020) Comparison of surface radiation and turbulent heat fluxes in Olympic Forest Park and on a building roof in Beijing, China. Urban Clim 31:100562. https://doi. org/10.1016/j.uclim.2019.100562

Kusaka H, Kimura F, Hirakuchi H, Mizutori M (2000) The effects of land-use alteration on the sea breeze and daytime heat island in the Tokyo Metropolitan Area. J Meteorol Soc Japan Ser II 78:405-420. https://doi.org/10.2151/jmsj1965.78.4_405

Kusaka H, Kondo H, Kikegawa Y, Kimura F (2001a) A simple singlelayer urban canopy model for atmospheric models: comparison with multi-layer and slab models. Bound Layer Meteorol 101:329-358. https://doi.org/10.1023/A:1019207923078

Kusaka H, Kondo H, Kikegawa Y, Kimura F (2001b) A simple singlelayer urban canopy model for atmospheric models: comparison with multi-layer and slab models. Bound Layer Meteorol. https ://doi.org/10.1023/A:1019207923078

Kusaka H, Chen F, Tewari M, Dudhia J, Gill DO, Duda MG et al (2012) Numerical simulation of urban heat island effect by the WRF model with 4-km grid increment: an inter-comparison study between the urban canopy model and slab model. J Meteorol Soc Jpn Ser II. https://doi.org/10.2151/jmsj.2012-B03

Kusaka H, Hara M, Takane Y (2012) Urban climate projection by the WRF model at 3-km horizontal grid increment: dynamical downscaling and predicting heat stress in the $\left.2070^{\wedge}\right|^{\wedge}$ rsquo;s August for Tokyo, Osaka, and Nagoya Metropolises. J Meteorol Soc Jpn Ser II 90B:47-63. https://doi.org/10.2151/jmsj.2012-B04

Kusaka H, Nawata K, Suzuki-Parker A, Takane Y, Furuhashi N (2014) Mechanism of precipitation increase with urbanization in Tokyo as revealed by ensemble climate simulations. J Appl Meteorol Climatol 53:824-839. https://doi.org/10.1175/JAMC-D-13-065.1

Kusaka H, Suzuki-Parker A, Aoyagi T, Adachi SA, Yamagata Y (2016) Assessment of RCM and urban scenarios uncertainties in the climate projections for August in the 2050s in Tokyo. Clim Change 137:427-438. https://doi.org/10.1007/s10584-016-1693-2

Kusaka H, Nishi A, Mizunari M, Yokoyama H (2019) Urban impacts on the spatiotemporal pattern of short-duration convective precipitation in a coastal city adjacent to a mountain range. Q J R Meteorol Soc 145:2237-2254. https://doi.org/10.1002/qj.3555

Labbé D, Boudreau J-A (2015) Local integration experiments in the new urban areas of Hanoi. South East Asia Res 23:245-262. https://doi.org/10.5367/sear.2015.0259

Lamptey B (2010) An analytical framework for estimating the urban effect on climate. Int J Climatol. https://doi.org/10.1002/joc.1873

Lauwaet D, Hooyberghs H, Maiheu B, Lefebvre W, Driesen G, Van Looy S et al (2015) Detailed urban heat island projections for cities worldwide: dynamical downscaling CMIP5 global climate models. Climate 3:391-415. https://doi.org/10.3390/cli3020391

Lee HS, Trihamdani AR, Kubota T, Iizuka S, Phuong TTT (2017) Impacts of land use changes from the Hanoi Master Plan 2030 on urban heat islands: part 2. influence of global warming. Sustain Cities Soc 31:95-108. https://doi.org/10.1016/j.scs.2017.02.015

Lemonsu A, Kounkou-Arnaud R, Desplat J, Salagnac JL, Masson V (2013) Evolution of the Parisian urban climate under a global changing climate. Clim Change 116:679-692. https://doi. org/10.1007/s10584-012-0521-6

Lenssen NJL, Schmidt GA, Hansen JE, Menne MJ, Persin A, Ruedy R et al (2019) Improvements in the GISTEMP uncertainty model. J Geophys Res Atmos. https://doi.org/10.1029/2018JD029522

Liang P, Ding Y (2017) The long-term variation of extreme heavy precipitation and its link to urbanization effects in Shanghai during 1916-2014. Adv Atmos Sci 34:321-334. https://doi.org/10.1007/ s00376-016-6120-0

Liao W, Wang D, Liu X, Wang G, Zhang J (2017) Estimated influence of urbanization on surface warming in Eastern China using timevarying land use data. Int J Climatol 37:3197-3208. https://doi. org/10.1002/joc. 4908

Li D, Bou-Zeid E (2013) Synergistic interactions between urban heat islands and heat waves: the impact in cities is larger than the sum of its parts. J Appl Meteorol Climatol 52:2051-2064. https://doi. org/10.1175/JAMC-D-13-02.1

Li M, Mao Z, Song Y, Liu M, Huang X (2015) Impacts of the decadal urbanization on thermally induced circulations in eastern China. J Appl Meteorol Climatol 54:259-282. https://doi.org/10.1175/ JAMC-D-14-0176.1

Li H, Cui X, Zhang DL (2017) Sensitivity of the initiation of an isolated thunderstorm over the Beijing metropolitan region to urbanization, terrain morphology and cold outflows. Q J R Meteorol Soc 143:3153-3164. https://doi.org/10.1002/qj.3169

Li H, Zhou Y, Li X, Meng L, Wang X, Wu S et al (2018) A new method to quantify surface urban heat island intensity. Sci Total Environ 624:262-272. https://doi.org/10.1016/j.scitotenv.2017.11.360

Li X, Mitra C, Dong L, Yang Q (2018) Understanding land use change impacts on microclimate using Weather Research and Forecasting (WRF) model. Phys. Chem Earth Parts A/B/C 103:115-126. https://doi.org/10.1016/j.pce.2017.01.017

Lokoshchenko MA (2017) Urban heat island and urban dry island in Moscow and their centennial changes. J Appl Meteorol Climatol 56:2729-2745. https://doi.org/10.1175/JAMC-D-16-0383.1

Mahmood R, Pielke RA, Hubbard KG, Niyogi D, Dirmeyer PA, Mcalpine $C$ et al (2014) Land cover changes and their biogeophysical 
effects on climate. Int J Climatol 34:929-953. https://doi. org/10.1002/joc.3736

Martilli A, Clappier A, Rotach MW (2002) An urban surface exchange parameterisation for mesoscale models. Bound Layer Meteorol. https://doi.org/10.1023/A:1016099921195

Masson V (2000) A Physically-Based Scheme For The Urban Energy Budget In Atmospheric Models. Bound Layer Meteorol 94:357397. https://doi.org/10.1023/A:1002463829265

Masson V (2006) Urban surface modeling and the meso-scale impact of cities. Theor Appl Climatol. https://doi.org/10.1007/s0070 4-005-0142-3

Masson V, Gomes L, Pigeon G, Liousse C, Pont V, Lagouarde J-P et al (2008) The Canopy and Aerosol Particles Interactions in TOulouse Urban Layer (CAPITOUL) experiment. Meteorol Atmos Phys 102:135. https://doi.org/10.1007/s00703-008-0289-4

Masson V, Lemonsu A, Hidalgo J, Voogt J (2020) Urban climates and climate change. Annu Rev Environ Resour 45:411-444. https:// doi.org/10.1146/annurev-environ-012320-083623

Ma S, Pitman A, Hart M, Evans JP, Haghdadi N, MacGill I (2017) The impact of an urban canopy and anthropogenic heat fluxes on Sydney's climate. Int J Climatol 37:255-270. https://doi. org/10.1002/joc.5001

McCarthy MP, Best MJ, Betts RA (2010) Climate change in cities due to global warming and urban effects. Geophys Res Lett. https:// doi.org/10.1029/2010GL042845

Mccarthy MP, Harpham C, Goodess CM, Jones PD (2012) Simulating climate change in UK cities using a regional climate model, HadRM3. Int J Climatol 32:1875-1888. https://doi.org/10.1002/ joc. 2402

McLeod J, Shepherd M, Konrad CE (2017) Spatio-temporal rainfall patterns around Atlanta, Georgia and possible relationships to urban land cover. Urban Clim 21:27-42. https://doi. org/10.1016/j.uclim.2017.03.004

Meier F, Fenner D, Grassmann T, Otto M, Scherer D (2017) Crowdsourcing air temperature from citizen weather stations for urban climate research. Urban Clim 19:170-191. https://doi. org/10.1016/j.uclim.2017.01.006

Mestayer PG, Durand P, Augustin P, Bastin S, Bonnefond J-M, Bénech B et al (2005) The urban boundary-layer field campaign in marseille (ubl/clu-escompte): set-up and first results. Bound Layer Meteorol 114:315-365. https://doi.org/10.1007/s1054 6-004-9241-4

Muller CL, Chapman L, Grimmond CSB, Young DT, Cai X (2013) Sensors and the city: a review of urban meteorological networks. Int J Climatol 33:1585-1600. https://doi.org/10.1002/joc.3678

Muller CL, Chapman L, Johnston S, Kidd C, Illingworth S, Foody G et al (2015) Crowdsourcing for climate and atmospheric sciences: current status and future potential. Int J Climatol 35:3185-3203. https://doi.org/10.1002/joc.4210

Nakatani T, Shusse Y, Shoji Y, Maesaka T, Sugawara H, Misumi R et al (2015) Tokyo metropolitan area convection study for extreme weather resilient cities. Bull Am Meteorol Soc. https://doi. org/10.1175/bams-d-14-00209.1

Oke T (2006) Initila guidance to obtain representative meteorological observations at urban sites. https://library.wmo.int/index .php?lvl=notice_display\&id=9262\#.X74cTu17k2w. Accessed 25 Nov 2020

Oke TR, Mills G, Christen A, Voogt JA (2017) Urban climates. Cambridge University Press, Cambridge. https://doi. org/10.1017/9781139016476

Oleson K (2012) Contrasts between Urban and rural climate in CCSM4 CMIP5 climate change scenarios. J Clim 25:1390-1412. https:// doi.org/10.1175/JCLI-D-11-00098.1
Oleson KW, Bonan GB, Feddema J, Jackson T (2011) An examination of urban heat island characteristics in a global climate model. Int J Climatol 31:1848-1865. https://doi.org/10.1002/joc.2201

Ooi MCG, Chan A, Ashfold MJ, Morris KI, Oozeer MY, Salleh SA (2017) Numerical study on effect of urban heating on local climate during calm inter-monsoon period in greater Kuala Lumpur, Malaysia. Urban Clim 20:228-250. https://doi.org/10.1016/j. uclim.2017.04.010

Pathirana A, Denekew HB, Veerbeek W, Zevenbergen C, Banda AT (2014) Impact of urban growth-driven landuse change on microclimate and extreme precipitation-a sensitivity study. Atmos Res 138:59-72. https://doi.org/10.1016/j.atmosres.2013.10.005

Polydoros A, Mavrakou T, Cartalis C (2018) Quantifying the trends in land surface temperature and surface urban heat island intensity in mediterranean cities in view of smart urbanization. Urban Sci 2:16. https://doi.org/10.3390/urbansci2010016

Rafael S, Martins H, Marta-Almeida M, Sà E, Coelho S, Rocha A et al (2017) Quantification and mapping of urban fluxes under climate change: application of WRF-SUEWS model to Greater Porto area (Portugal). Environ Res 155:321-334. https://doi. org/10.1016/j.envres.2017.02.033

Robaa SM (2013) Some aspects of the urban climates of Greater Cairo Region, Egypt. Int J Climatol 33:3206-3216. https://doi. org/10.1002/joc.3661

Rosenzweig C, Solecki W, Romero-Lankao P, Mehrotra S, Dhakal S, Bowman T et al (2018) Climate change and cities: second assessment report of the urban climate change research network. In: Rosenzweig C, Romero-Lankao P, Mehrotra S, Dhakal S, Ibrahim SA, Solecki WD (eds) Climate change and cities: second assessment report of the urban climate change research network. Cambridge University Press, Cambridge, pp 17-42. https://doi. org/10.1017/9781316563878.007

Rotach MW, Vogt R, Bernhofer C, Batchvarova E, Christen A, Clappier A et al (2005) BUBBLE-an urban boundary layer meteorology project. Theor Appl Climatol 81:231-261. https://doi. org/10.1007/s00704-004-0117-9

Roth M, Inagaki A, Sugawara H, Kanda M (2015) Small-scale spatial variability of turbulence statistics, (co)spectra and turbulent kinetic energy measured over a regular array of cube roughness. Environ Fluid Mech 15:329-348. https://doi.org/10.1007/s1065 2-013-9322-3

Sachindra DA, Ng AWM, Muthukumaran S, Perera BJC (2016) Impact of climate change on urban heat island effect and extreme temperatures: a case-study. Q J R Meteorol Soc 142:172-186. https ://doi.org/10.1002/qj.2642

Salmond JA, Roth M, Oke TR, Christen A, Voogt JA (2012) Can surface-cover tiles be summed to give neighborhood fluxes in cities? J Appl Meteorol Climatol 51:133-149. https://doi.org/10.1175/ JAMC-D-11-078.1

Schlünzen KH, Hoffmann P, Rosenhagen G, Riecke W (2010) Longterm changes and regional differences in temperature and precipitation in the metropolitan area of Hamburg. Int J Climatol 30:1121-1136. https://doi.org/10.1002/joc.1968

Schmid PE, Niyogi D (2014) Modeling urban precipitation modification by spatially heterogeneous aerosols. J Appl Meteorol Climatol 56:2141-2153. https://doi.org/10.1175/JAMC-D-16-0320.1

Secerov I, Savic S, Milošević D, Markovic V, Bajsanski I, Ivan Š et al (2015) Development of an automated urban climate monitoring system in Novi Sad (Serbia) TI2. Geographica Pannonica. https ://doi.org/10.5937/geopan1504174s

Šećerov IB, Savić SM, Milošević DD, Arsenović DM, Dolinaj DM, Popov SB (2019) Progressing urban climate research using a high-density monitoring network system. Environ Monit Assess 191:89. https://doi.org/10.1007/s10661-019-7210-0 
Seino N, Aoyagi T, Tsuguti H (2018) Numerical simulation of urban impact on precipitation in Tokyo: how does urban temperature rise affect precipitation? Urban Clim 23:8-35. https://doi. org/10.1016/j.uclim.2016.11.007

Seto KC, Golden JS, Alberti M, Turner BL (2017) Sustainability in an urbanizing planet. Proc Natl Acad Sci 114:8935-8938. https:// doi.org/10.1073/pnas.1606037114

Shastri H, Paul S, Ghosh S, Karmakar S (2015) Impacts of urbanization on Indian summer monsoon rainfall extremes. J Geophys Res Atmos 120:496-516. https://doi.org/10.1002/2014JD022061

Singh J, Vittal H, Karmakar S, Ghosh S, Niyogi D (2016) Urbanization causes nonstationarity in Indian Summer Monsoon Rainfall extremes. Geophys Res Lett 43:11269-11277. https://doi. org/10.1002/2016GL071238

Skarbit N, Stewart ID, Unger J, Gál T (2017) Employing an urban meteorological network to monitor air temperature conditions in the 'local climate zones' of Szeged, Hungary. Int J Climatol 37:582-596. https://doi.org/10.1002/joc.5023

Song Y, Liu H, Wang X, Zhang N, Sun J (2016) Numerical simulation of the impact of urban non-uniformity on precipitation. Adv Atmos Sci 33:783-793

Sugawara H, Inagaki A, Roth M, Kanda M (2016) Evaluation of scintillometery measurements of fluxes of momentum and sensible heat in the roughness sublayer. Theor Appl Climatol 126:673681. https://doi.org/10.1007/s00704-015-1556-1

Sun Y, Zhang X, Ren G, Zwiers FW, Hu T (2016) Contribution of urbanization to warming in China. Nat Clim Change 6:706-709. https://doi.org/10.1038/nclimate2956

Termonia P, Fischer C, Bazile E, Bouyssel F, Brožková R, Bénard $P$ et al (2018) The ALADIN System and its canonical model configurations AROME CY41T1 and ALARO CY40T1. Geosci. Model Dev 11:257-281. https://doi.org/10.5194/ gmd-11-257-2018

Torres-Valcárcel ÁR, Harbor J, Torres-Valcárcel AL, González-Avilés CJ (2015) Historical differences in temperature between urban and non-urban areas in Puerto Rico. Int J Climatol 35:16481661. https://doi.org/10.1002/joc.4083

Tran DN, Van DQ, Kusaka H, Seposo XT, Honda Y (2018) Green space and deaths attributable to the urban heat island effect in Ho Chi Minh City. Am J Public Health 108:S137-S143. https:// doi.org/10.2105/AJPH.2017.304123

Trusilova K, Jung M, Churkina G, Karsten U, Heimann M, Claussen M (2008) Urbanization impacts on the climate in Europe: numerical experiments by the PSU-NCAR mesoscale model (MM5). J Appl Meteorol Climatol 47:1442-1455. https://doi.org/10.1175/2007J AMC1624.1

Trusilova K, Schubert S, Wouters H, Früh B, Grossman-Clarke S, Demuzere $\mathrm{M}$ et al (2016) The urban land use in the COSMOCLM model: a comparison of three parameterizations for Berlin. Meteorol Zeitschrift 25:231-244. https://doi.org/10.1127/ metz/2015/0587

Wang J, Yan Z, Quan XW, Feng J (2017) Urban warming in the 2013 summer heat wave in eastern China. Clim Dyn 48:3015-3033. https://doi.org/10.1007/s00382-016-3248-7

Wang K, Li Y, Luo Z, Yin S, Chan PW (2018) Harmonic analysis of 130-year hourly air temperature in Hong Kong: detecting urban warming from the perspective of annual and daily cycles. Clim Dyn 51:613-625. https://doi.org/10.1007/s00382-017-3944-y

Ward K, Lauf S, Kleinschmit B, Endlicher W (2016) Heat waves and urban heat islands in Europe: a review of relevant drivers. Sci Total Environ 569-570:527-539. https://doi.org/10.1016/j.scito tenv.2016.06.119
Warner T, Benda P, Swerdlin S, Knievel J, Argenta E, Aronian B et al (2007) The pentagon shield field program: toward critical infrastructure protection. Bull Am Meteorol Soc 88:167-176. https ://doi.org/10.1175/BAMS-88-2-167

WMO (2017) WMO guidelines on generating a defined set of national climate monitoring products 2017. WMO, Geneva

Wood CR, Järvi L, Kouznetsov RD, Nordbo A, Joffre S, Drebs A et al (2013) An overview of the urban boundary layer atmosphere network in Helsinki. Bull Am Meteorol Soc 94:1675-1690. https ://doi.org/10.1175/BAMS-D-12-00146.1

Wu J, Zha J, Zhao D (2017) Evaluating the effects of land use and cover change on the decrease of surface wind speed over China in recent 30 years using a statistical downscaling method. Clim Dyn 48:131-149. https://doi.org/10.1007/s00382-016-3065-z

Yamato H, Mikami T, Takahashi H (2017) Impact of sea breeze penetration over urban areas on midsummer temperature distributions in the Tokyo Metropolitan area. Int J Climatol 37:5154-5169. https://doi.org/10.1002/joc.5152

Yan ZW, Wang J, Xia JJ, Feng JM (2016) Review of recent studies of the climatic effects of urbanization in China. Adv Clim Chang Res 5:454. https://doi.org/10.1016/j.accre.2016.09.003

Yoshikado H, Kondo H (1989) Inland penetration of the sea breeze over the suburban area of Tokyo. Bound Layer Meteorol 48:389407. https://doi.org/10.1007/BF00123061

Zhang N, Chen Y (2014) A case study of the upwind urbanization influence on the urban heat Island effects along the SuzhouWuxi corridor. J Appl Meteorol Climatol 53:333-345. https:// doi.org/10.1175/JAMC-D-12-0219.1

Zhang DL, Shou YX, Dickerson RR (2009) Upstream urbanization exacerbates urban heat island effects. Geophys Res Lett 36:1-5. https://doi.org/10.1029/2009GL041082

Zhang GJ, Cai M, Hu A (2013) Energy consumption and the unexplained winter warming over northern Asia and North America. Nat Clim Chang 3:466-470. https://doi.org/10.1038/nclimate18 03

Zhao L, Lee X, Smith RB, Oleson K (2014) Strong contributions of local background climate to urban heat islands. Nature 511:216219. https://doi.org/10.1038/nature 13462

Zhong S, Yang XQ (2015) Mechanism of urbanization impact on a summer cold-frontal rainfall process in the greater Beijing metropolitan area. J Appl Meteorol Climatol 54:1234-1247. https:// doi.org/10.1175/JAMC-D-14-0264.1

Zhong S, Qian Y, Zhao C, Leung R, Wang H, Yang B et al (2017) Urbanization-induced urban heat island and aerosol effects on climate extremes in the Yangtze River Delta region of China. Atmos Chem Phys 17:5439-5457. https://doi.org/10.5194/ acp-17-5439-2017

Zhou D, Zhang L, Hao L, Sun G, Liu Y, Zhu C (2016) Spatiotemporal trends of urban heat island effect along the urban development intensity gradient in China. Sci Total Environ 544:617-626. https ://doi.org/10.1016/j.scitotenv.2015.11.168

Zhou B, Rybski D, Kropp JP (2017) The role of city size and urban form in the surface urban heat island. Sci Rep 7:4791. https:// doi.org/10.1038/s41598-017-04242-2

Zhu X, Li D, Zhou W, Ni G, Cong Z, Sun T (2017) An idealized LES study of urban modification of moist convection. Q J R Meteorol Soc 143:3228-3243. https://doi.org/10.1002/qj.3176

Zipper SC, Schatz J, Kucharik CJ, Loheide SP (2017) Urban heat island-induced increases in evapotranspirative demand. Geophys Res Lett 44:873-881. https://doi.org/10.1002/2016GL072190 